\title{
Comparing observed and modelled growth of larval herring (Clupea harengus): Testing individual-based model parameterisations
}

\author{
HELENA M. HAUSS ${ }^{1}$ and MYRON A. PECK ${ }^{2}$ \\ ${ }^{1}$ Leibniz Institute of Marine Sciences, Düsternbrooker Weg 20, D-24105 Kiel, Germany. E-mail: hhauss@ifm-geomar.de \\ ${ }^{2}$ Institute of Hydrobiology and Fisheries Science, University of Hamburg, Olbersweg 24, D-22767 Hamburg, Germany.
}

\begin{abstract}
SUMmaRY: Experiments that directly test larval fish individual-based model (IBM) growth predictions are uncommon since it is difficult to simultaneously measure all relevant metabolic and behavioural attributes. We compared observed and modelled somatic growth of larval herring (Clupea harengus) in short-term (50 degree-day) laboratory trials conducted at 7 and $13^{\circ} \mathrm{C}$ in which larvae were either unfed or fed ad libitum on different prey sizes ( 100 to $550 \mu \mathrm{m}$ copepods, Acartia tonsa). The larval specific growth rate $\left(S G R, \% D W \mathrm{~d}^{-1}\right)$ was generally overestimated by the model, especially for larvae foraging on large prey items. Model parameterisations were adjusted to explore the effect of 1) temporal variability in foraging of individuals, and 2) reduced assimilation efficiency due to rapid gut evacuation at high feeding rates. With these adjustments, the model described larval growth well across temperatures, prey sizes, and larval sizes. Although the experiments performed verified the growth model, variability in growth and foraging behaviour among larvae shows that it is necessary to measure both the physiology and feeding behaviour of the same individual. This is a challenge for experimentalists but will ultimately yield the most valuable data to adequately model environmental impacts on the survival and growth of marine fish early life stages.
\end{abstract}

Keywords: IBM, marine fish, larval growth, feeding, behaviour, bioenergetics.

RESUMEN: COMPARACIÓN ENTRE CRECIMIENTO OBSERVAdo y PREDICHO DE LARVAS DE ARENQUE (CLUPEA HARENGUS): ANALIZANDO PARAMETRIZACIONES DE MODELOS BASADOS EN INDIVIDUOS. - Los experimentos que analizan directamente las predicciones de crecimiento generadas por modelos basados en individuos (IBM) son poco comunes puesto que resulta difícil medir simultáneamente todos los atributos metabólicos y conductuales. En este estudio, comparamos el crecimiento somático observado y el estimado a partir de modelos de larvas de arenque (Clupea harengus) en experimentos de laboratorio a corto plazo (50 grados-día) a 7 y $13^{\circ} \mathrm{C}$ en los que las larvas fueron mantenidas en condiciones de ayuno o recibieron alimentación ad libitum con diferentes tamaños de presa (copépodos, Acartia tonsa, de aproximadamente 100 a $500 \mu \mathrm{m}$ ). Las estimas de tasa específica de crecimiento ( $S G R$, \% de peso seco por día) fueron, en general, sobreestimadas por el modelo, especialmente para larvas que se alimentaron con presas grandes. Las estimas del modelo se ajustaron a dos escenarios para explorar el efecto de 1) variabilidad temporal en la alimentación de las larvas, y 2) disminución en la eficiencia de asimilación debida una rápida evacuación del tubo digestivo a tasas de alimentación altas. Con estos ajustes, el modelo describió bien el crecimiento larvario para temperaturas, tamaños de presa y edades de las larvas, indicando que las parametrizaciones metabólicas son robustas. Aunque los experimentos llevados a cabo con grupos de larvas verificaron los modelos de crecimiento, la variabilidad en el crecimiento y conducta de alimentación entre larvas sometidas a las mismas condiciones ambientales ponen de relieve la necesidad de que las medidas fisiológicas y de conducta vayan emparejadas y sean tomadas a nivel individual. Esto representa un reto para los experimentalistas, pero a largo plazo generará datos valiosos para los modeladores encargados de simular efectos ambientales sobre las tasas vitales de estadíos tempranos de desarrollo de peces marinos.

Palabras clave: IBM, modelado basado en individuos, larvas de arenque, conducta de alimentación, bioenergética. 


\section{INTRODUCTION}

Biophysical individual-based models (IBMs) have been recognised as important tools for understanding how environmental conditions influence larval fish growth and survival (e.g. see reviews by Werner et al., 2001; Miller, 2007). Larval fish IBMs differ in the complexity of their biological components depending on the research questions asked. For example, some models ignore mechanistic depictions of feeding and/or growth and employ relatively simple temperature-growth functions, making the assumption that larval growth rates do not depend on variability in prey fields encountered along drift routes (Heath et al., 1997; Hinrichsen et al., 2003). However, some IBMs have been created to explore bottom-up regulation of survival and include highly detailed, mechanistic descriptions of growth physiology and foraging (Fiksen and MacKenzie, 2002; Lough et al., 2005; Ruzicka and Gallager, 2006). The reliability of physiologically-based growth estimates generated by these more complex IBMs depends on their ability to correctly depict how key abiotic and biotic factors influence the processes of foraging and growth.

In many larval fish IBMs, growth rates are calculated at each time step using a balanced energy budget (units of dry mass or energy per unit time):

$$
G=C \beta(1-S D A)-R,
$$

where growth $(G)$ is a function of consumed prey $(C)$, assimilation efficiency of food $(\beta)$, costs due to digestion and protein synthesis (specific dynamic action, $S D A)$ and total respiration $(R)$. Respiratory costs are separated into inactive (standard metabolism, $R_{\mathrm{S}}$ ) and active foraging $\left(R_{\mathrm{A}}\right)$ periods (Brett and Groves, 1979). The amount of food consumed at each time step is normally calculated using a separate foraging routine. An optimal foraging approach has been implemented in some larval fish IBMs (Walton et al., 1992) based on changes in the prey encounter rate, capture success and handling time at different predator and prey sizes (Fiksen and Folkvord, 1999; Peck and Daewel, 2007; Daewel et al., 2008). In theory, capturing relatively large prey items has a greater reward in energy gain $(C$ increased) but larvae may incur greater costs $(R)$ in terms of time spent swimming and searching, especially if larger prey are relatively less abundant and are not captured as efficiently when encountered. However, the ability of larval IBMs to capture the costs and tradeoffs (in terms of growth) of larvae feeding on prey of different sizes has not, to our knowledge, been previously tested (for example, by comparison with observations). This is due to a general lack of adequate data collected in controlled laboratory experiments performed on modelled species.

Efforts are now underway to parameterise an individual-based model that includes optimal foraging and growth of Atlantic herring (Clupea harengus) larvae in the North Sea. Atlantic herring is a particularly well-studied species (e.g., Folkvord et al., 2009; Geffen, 2009). A number of experimental studies have provided detailed descriptions and quantitative estimates of the components of Equation 1 and of key aspects of foraging, including factors influencing swimming behaviour, the perception of prey, feeding ability and prey capture success (e.g., Blaxter, 1968; Rosenthal, 1969; Munk and Kiørboe, 1985; Kiørboe et al., 1987; Munk, 1992; Hauss, 2008). In the present study, we combined parameterisations for Equation 1 previously employed in larval clupeid IBMs (Peck and Daewel, 2007; Daewel et al., 2008) with new observations of larval herring foraging behaviour, food consumption and growth (Hauss, 2008; Peck, unpublished data) at different temperatures, larval ages and prey sizes. In the present study, we compared these new estimates of observed growth rates with those predicted by larval IBM foraging and growth subroutines. Particular emphasis was placed on assessing whether current IBM formulations correctly reflect the costs and benefits (in terms of larval growth) for larvae foraging within different prey environments.

\section{MATERIALS AND METHODS}

\section{Observations of larval herring}

The foraging behaviour, growth and nutritional condition of Atlantic herring larvae in different prey environments were investigated in short-term growth trials (Hauss, 2008). Four trials were conducted using two temperatures $\left(7\right.$ and $\left.13^{\circ} \mathrm{C}\right)$ and two fish sizes $(\sim 10 \mathrm{~mm}$ and $15 \mathrm{~mm}$ standard length, $S L)$. In each case, trials were conducted within temperaturecontrolled rooms for approximately 50 degree-days $\left(\mathrm{T}^{*} \mathrm{~d}\right)$, resulting in four days at $13^{\circ} \mathrm{C}$ and seven days at $7^{\circ} \mathrm{C}$. Surface light intensities were $\sim 5-10 \mu \mathrm{mol} \mathrm{m} \mathrm{m}^{-2}$ $\mathrm{s}^{-1}$ during a $14 \mathrm{~h}$ photoperiod (14:10, L:D). In each 
TABLE 1. - Equations and parameters used to model the daily growth rate based on food consumption in larval clupeid IBMs. $P L=$ copepod prosome length $(\mathrm{mm}), S L=$ larval standard length $(\mathrm{mm}), D W=$ dry weight $(\mu \mathrm{g})$.

\begin{tabular}{|c|c|c|c|}
\hline Parameter & Abbreviation & Unit & Equation \\
\hline $\begin{array}{l}\text { [1] prey capture success } \\
\text { [2] A. tons } a \text { prosome length } P L(\mathrm{~mm})\end{array}$ & $C S$ & dimensionless & $\mathrm{CS}=1.1-13.6 *\left(P L_{\text {prey }} / S L_{\text {predator }}\right)$ \\
\hline $\begin{array}{l}\text { to dry weight conversion } \\
\text { to }\end{array}$ & $D W$ & $\mu \mathrm{g}$ & $D W=7.95 * 10^{-9} * P L^{3.31}$ \\
\hline [3] assimilation efficiency & $\beta$ & dimensionless & $\beta=0.7 *\left(1.0-0.3 * e^{\left(-0.003 * D W-D W_{M I N}\right)}\right)$ \\
\hline [4] specific dynamic action & $S D A$ & dimensionless & $S D A=0.11+4.91 * 10^{-7} * D W$ \\
\hline [5] standard respiration & $R_{\mathrm{S}}$ & $\mu l \mathrm{O}_{2} * \mathrm{~h}^{-1}$ & $R_{\mathrm{S}}=4.35^{*} D W^{0.82 *} Q_{10}((\mathrm{~T}-8) / 10)$ \\
\hline [6] active respiration & $R_{\mathrm{A}}$ & $\mu \mathrm{O}_{2}^{2} * \mathrm{~h}^{-1}$ & $R_{\mathrm{A}}^{\mathrm{S}}=k^{*} R_{\mathrm{S}}$ \\
\hline [7] activity multiplier & $k^{\mathrm{A}}$ & dimensionless & $k=2.0$ \\
\hline [8] oxycaloric conversion & & dimensionless & $0.00463 * \mathrm{cal}^{*} \mathrm{ulO}^{-1}$ \\
\hline [9] calorie to larval $D W$ conversion & & dimensionless & $227.0 \mu \mathrm{g} \mathrm{DW} * \mathrm{cal}^{-1}$ \\
\hline [10] gut capacity & $G u t_{\mathrm{CAP}}$ & $\mu \mathrm{g}$ & Gut $_{\mathrm{CA \textrm {P }}}=0.0306 * D W$ \\
\hline [11] gut evacuation rate & GER & $\mathrm{h}^{-1}$ & $G E R=1.79 * S L^{-0.83 *} Q_{10}{ }^{((\mathrm{T}-12) / 10) * 3}$ \\
\hline
\end{tabular}

References: [1] Munk (1992); [2] Berggreen et al. (1988); [3] Buckley and Dillman (1982); [4] Hermann and Peck unpubl.; [5] Kiørboe et al. (1987), Peck and Daewel (2007); [7] Peck unpubl.; [8] Brett and Groves (1979); [9]Theilacker and Kimball (1984); [10] Pepin and Penney (2000); [11] Peck and Daewel (2007).

trial, a total of eleven, 16-L cylindrical $(\varnothing 35 \mathrm{~cm})$ plastic tanks was used: groups of larvae were either unfed (two tanks) or provided "small", "medium" or "large" copepod (Acartia tonsa) size fractions (three tanks at each prey size). Larvae ( $\mathrm{n}=15$ to 17$)$ were randomly loaded into tanks and into an initial group $(\mathrm{n}=15)$. All tanks were gently aerated and "greened" with Rhodomonas to $\sim 50000$ cells $\mathrm{ml}^{-1}$. Copepods were size fractionated by using progressively smaller sieves $(150,90$ and $37 \mu \mathrm{m})$, stained with Lugol's solution and immediately photographed under a dissecting scope to determine prosome lengths. The range of mean prosome lengths was 130 to $170 \mu \mathrm{m}, 190$ to $330 \mu \mathrm{m}$ and 385 to 560 um for "small", "medium" and "large" prey items respectively. Within each trial for each prey size, ad libitum prey concentrations ( 1 to 2 prey items $\mathrm{ml}^{-1}$ ) were provided at the start of the experiment (and the same, size-fractionated copepod cohort was supplied again at mid-trial if necessary). One tank per prey size treatment was made of transparent plastic, which allowed behavioural observations to be made. Specifically, the feeding strike frequency $\left(\right.$ no $\left.\mathrm{min}^{-1}\right)$ of free-swimming larvae was recorded each day ( $n=5$ observations per tank, 3 min each) in each prey treatment. If a larva swam along the tank walls or the water surface, the measurement was stopped and another larva was selected. This observation was repeated five times per treatment and we attempted to choose different individuals each time.

At the end of each trial, the copepods remaining in the tanks were counted and their prosome lengths determined. Each larva was digitally photographed while alive, their $S L$ measured to the nearest $0.1 \mathrm{~mm}$ (Optimas image analysis) and immediately frozen at $-80^{\circ} \mathrm{C}$. Larvae from all tanks (and larvae within the initial sample) were freeze-dried and their $D W$ measured to the nearest $0.1 \mu \mathrm{g}$ (Sartorius SC2 microbalance). For growth estimates, tank mean values of larval $D W$ were calculated and compared to the mean $D W$ of the initial group. The larval weight-specific growth rate $\left(S G R, \% D W \mathrm{~d}^{-1}\right)$ was calculated for each tank, and then treatment means were calculated. Unfortunately, due to an equipment failure, measurements of larval $D W$ could not be obtained in one trial and, in this case, we estimated the $D W$ from the measured $S L$ of the experimental larvae based on known weight-length relationships for larvae in that laboratory cohort (rearing tank kept at the same temperature). More details on the algal, copepod and herring larvae cultures and analyses are presented in Hauss (2008).

\section{Modelling of larval herring}

The growth (SGR, \% DW $\left.\mathrm{d}^{-1}\right)$ of unfed and fed larvae was based on Equation 1. Unfed larvae lost weight due to metabolic costs $(R)$. Minimum levels of swimming activity have been previously observed for herring larvae at light intensities below the foraging threshold (Batty, 1987), and thus $R$ was partitioned into standard $\left(R_{S}\right)$ and active $\left(R_{A}\right)$ respiration during the $10 \mathrm{~h}$ dark and $14 \mathrm{~h}$ light period respectively (Table 1, Eqs. [5] to [9]). In fed larvae, food consumption was estimated from the feeding activity measured at each of the three prey sizes. Since herring larvae are visual feeders that are not able to perceive their prey in the dark (Blaxter, 1968), food consumption was only considered possible during the $14 \mathrm{~h}$ photoperiod. The tank mean feeding strike frequency over the entire experimental period was 
used to calculate a daily, treatment- (prey size-) specific food consumption rate ( $C$ in Eq. 1$)$ that included a size-specific capture success $(C S)$ function (Table 1, Eq. [1]) previously reported for Atlantic herring feeding on the same copepod species used as prey in the present trials (Munk, 1992). The number of copepods consumed was converted into $\mu \mathrm{g}$ dry mass (Berggreen et al., 1988) using the mean of the copepod prosome lengths measured at the beginning and end of the trial for each prey size treatment (Table 1, Eq. [2]). Parameters describing assimilation efficiency of food $(\beta)$ and costs due to digestion and protein synthesis $(S D A)$ were taken from the literature (Table 1, Eqs. [3] and [4]). We did not attempt to limit $G$ by introducing a maximum growth term since we wished to investigate the performance of a model that included mechanistic growth constraints (see Peck and Daewel, 2007).

After an initial comparison of observed and predicted growth, the budget (Eq. 1) was adjusted using two different scenarios based on expected differences between laboratory and field conditions and potentially among individual larvae. First, temporal or inter-individual variability in feeding among larvae was explored. In this scenario, a single factor $(\alpha)$ was applied to reduce feeding strike frequency observed in all treatments and trials. The value of $\alpha$ was determined statistically by minimizing the sum of squared errors (SSE) between modelled and observed $G$ where the latter was based on a mean value calculated for the three tanks at each prey size in a trial (total $n=12$; three feeding treatments in each of the four trials). A second scenario investigated the possibility of decreased assimilation efficiency $(\beta)$ due to intensive rates of feeding within prey patches (Peck and Daewel, 2007) or unrealistically high prey concentrations used in the laboratory. In this case, a theoretical weight of copepods that could be consumed each day $\left(C_{\mathrm{MAX}}\right)$ was calculated based on maximum weight-specific gut capacity $G u t_{\mathrm{CAP}}$ according to the prey found in field-caught herring larvae (Pepin and Penney, 2000, Table 1, Eq. [10]) and gut evacuation rate (Table 1, Eq. [11]). In cases in which estimated $C$ exceeded $C_{\mathrm{MAX}}$, assimilation efficiency $\beta$ was reduced by $C_{\mathrm{MAX}} * C^{-1}$, so that

$$
\beta^{\prime}=\beta^{*} C_{\mathrm{MAX}} * C^{-1} \text {, if } C>C_{\mathrm{MAX}}
$$

To assess the "goodness of fit", linear regression analyses were performed on modelled and observed

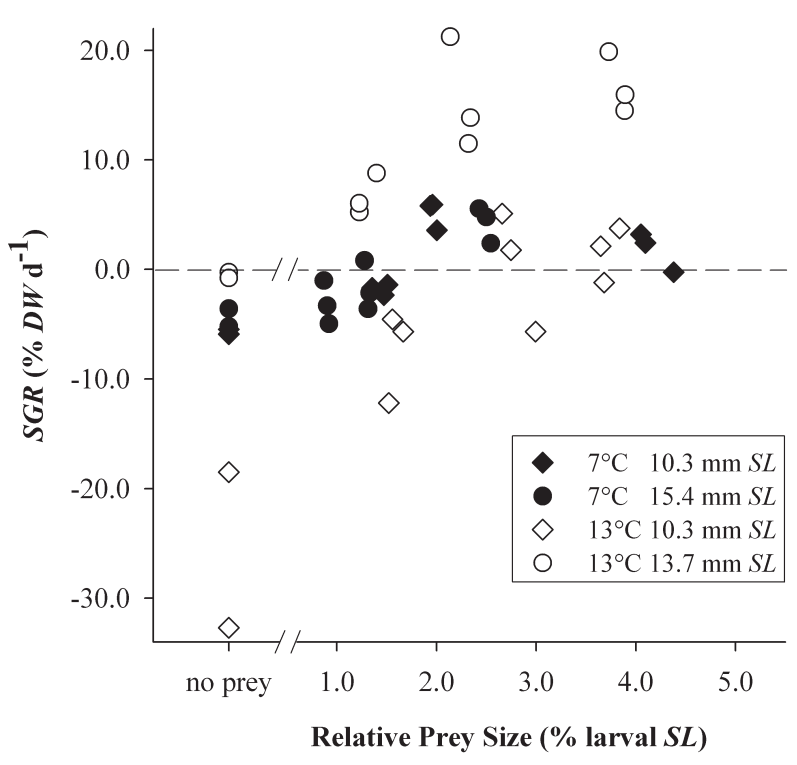

Fig. 1. - Observed specific growth rate $\left(S G R, \% D W \mathrm{~d}^{-1}\right)$ for the four growth trials (two larval ages, two temperatures) at starvation conditions and at different relative prey sizes (\% larval $S L$ ). Values are tank means. The dashed line indicates zero growth.

values. Modelled growth rates include those in the original "base case" and within each of the two adjusted scenarios. Residuals ( $\left.S G R_{\mathrm{OBS}}-S G R_{\mathrm{PRED}}\right)$ of these regressions were calculated to determine whether modelled growth rates were biased at specific temperatures, larval ages/sizes or prey sizes.

\section{RESULTS AND DISCUSSION}

\section{Observed growth and foraging activity}

Mean larval growth rates in the replicate tanks of the "feeding" treatments ranged between -12.2 and $21.2 \% D W \mathrm{~d}^{-1}$ for larvae at $13^{\circ} \mathrm{C}$ (Fig. 1, open sym-

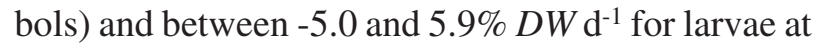
$7^{\circ} \mathrm{C}$ (Fig. 1, filled symbols). To be able to compare growth across different larval sizes, prey size was expressed in relative length $\left(100 * P L_{\text {prey }} * S L_{\text {larvae }}{ }^{-1}\right)$. Compared to the group of larvae measured at the start of the trial, unfed larvae lost weight and mean $S G R$ in these tanks ranged from -32.0 to $-0.3 \% \mathrm{~d}^{-1}$. Negative $S G R$ (weight loss) was also observed in larvae foraging on the smallest and largest prey items, while larvae foraging on intermediate-sized prey had the highest $S G R(\sim 3 \% S L)$. Compared to previous studies in which herring larvae were reared in the laboratory (Werner and Blaxter, 1980; McGurk, 1984; Folkvord et al., 2000), growth rates at optimum prey sizes in this study were quite high. In 
$7^{\circ} \mathrm{C} 10.3 \mathrm{~mm} \mathrm{SL}$

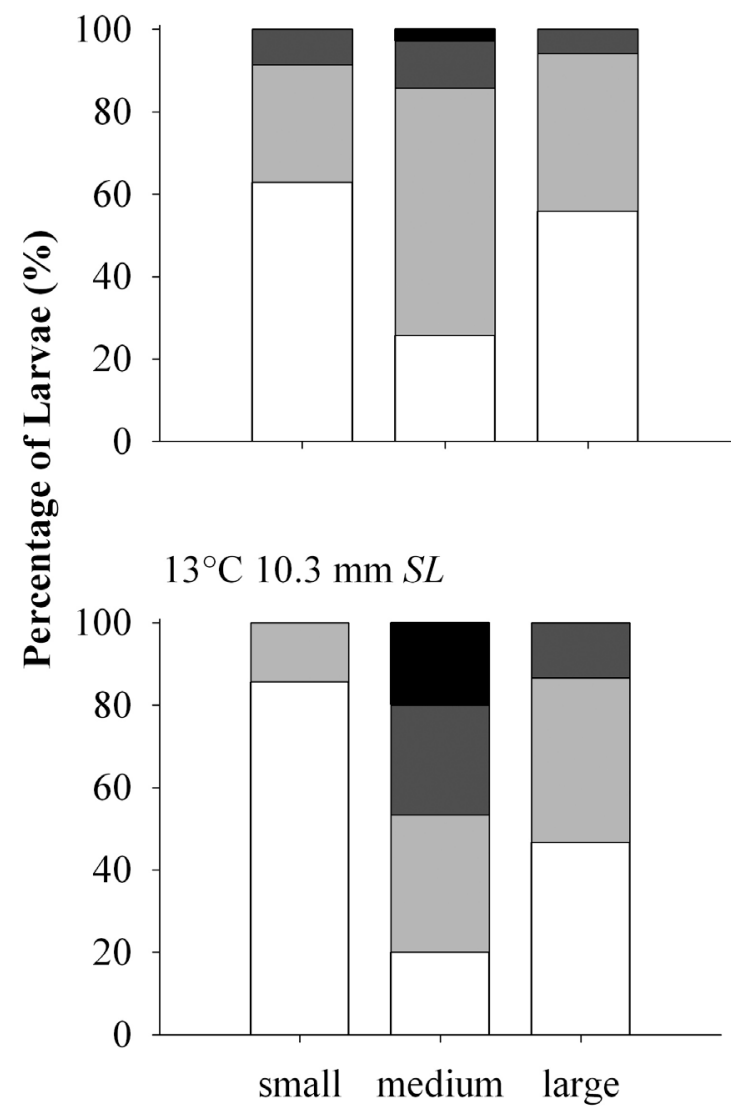

$7^{\circ} \mathrm{C} 15.4 \mathrm{~mm} \mathrm{SL}$

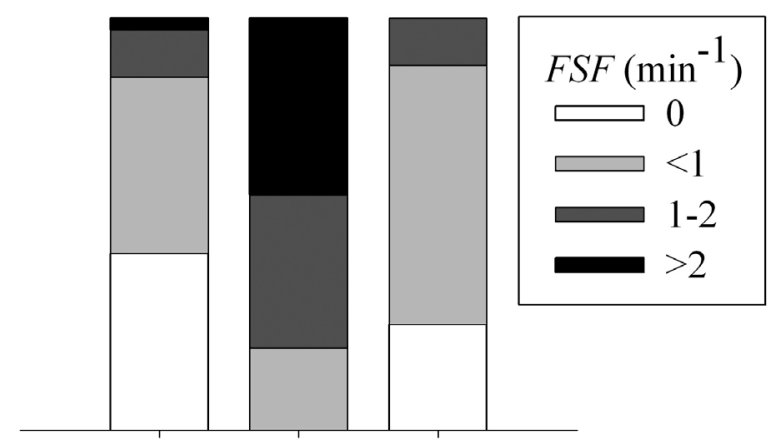

$13^{\circ} \mathrm{C} 13.7 \mathrm{~mm} \mathrm{SL}$

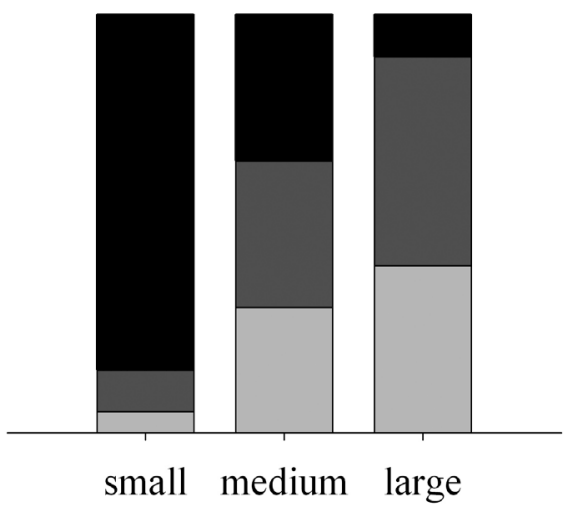

Prey Size Treatment

FIG. 2. - Feeding Strike Frequency $\left(F S F\right.$, no. $\left.\mathrm{min}^{-1}\right)$ ranges observed in the three different prey size treatments in each of the four growth trials.

general, maximum growth rates reported in field surveys and mesocosm experiments are more variable; however, growth measured at sea may be artificially high due to higher mortality rates of ill-nourished, slower-growing larvae (Skajaa et al., 2003).

Observed foraging (feeding strike frequency, $F S F$ ) (Fig. 2) was impacted by prey size treatment, temperature and larval age. Generally, older/larger larvae and larvae at the higher temperature fed more intensively than younger/smaller larvae and those at the lower temperature. However, individual variability in feeding strike frequency was large (Fig. 2); feeding strikes were not observed for many individuals during the three-minute observation period. Average ( \pm standard deviation, SD) FSF ranged between $0.25( \pm 0.23)$ and $5.5( \pm 3.7) \mathrm{min}^{-1}$. The highest feeding strike frequencies were recorded in the second $13^{\circ} \mathrm{C}$ trial, particularly for larvae feeding on the small prey size, where FSF increased with time (see Hauss, 2008). In all other experiments, the larvae showed the highest feeding rate at the medium prey size.

\section{Base case}

In the unadjusted budget, modelled and observed growth agreed poorly (Fig. 3A, note scaling on y-axis and position of 1:1 line). The former being substantially higher, particularly in cases where larvae were provided medium and large prey sizes for which the mean $( \pm \mathrm{SD})$ residual values were $-45.3( \pm 30.5)$ and $-48.5( \pm 16.7)$ respectively. For larvae experiencing poor feeding conditions, mean $( \pm \mathrm{SD})$ residual values were $0.4( \pm 10.2)$ and $-11.4( \pm 22.9)$ for "no prey" and "small prey" treatments respectively, indicating that parameterisations of metabolic losses in unfed larvae were robust. Furthermore, estimates at $7^{\circ} \mathrm{C}$ were better and less variable than at $13^{\circ} \mathrm{C}$ with mean $( \pm \mathrm{SD})$ residuals of $-13.1( \pm 15.8)$ and $-39.9( \pm 34.2)$ respectively, and the size/age of larvae did not impact predictions.

A key parameter that is particularly challenging to estimate is the activity multiplier $(k)$ that converts inactive rates $\left(R_{\mathrm{S}}\right)$ to rates used during daytime for- 

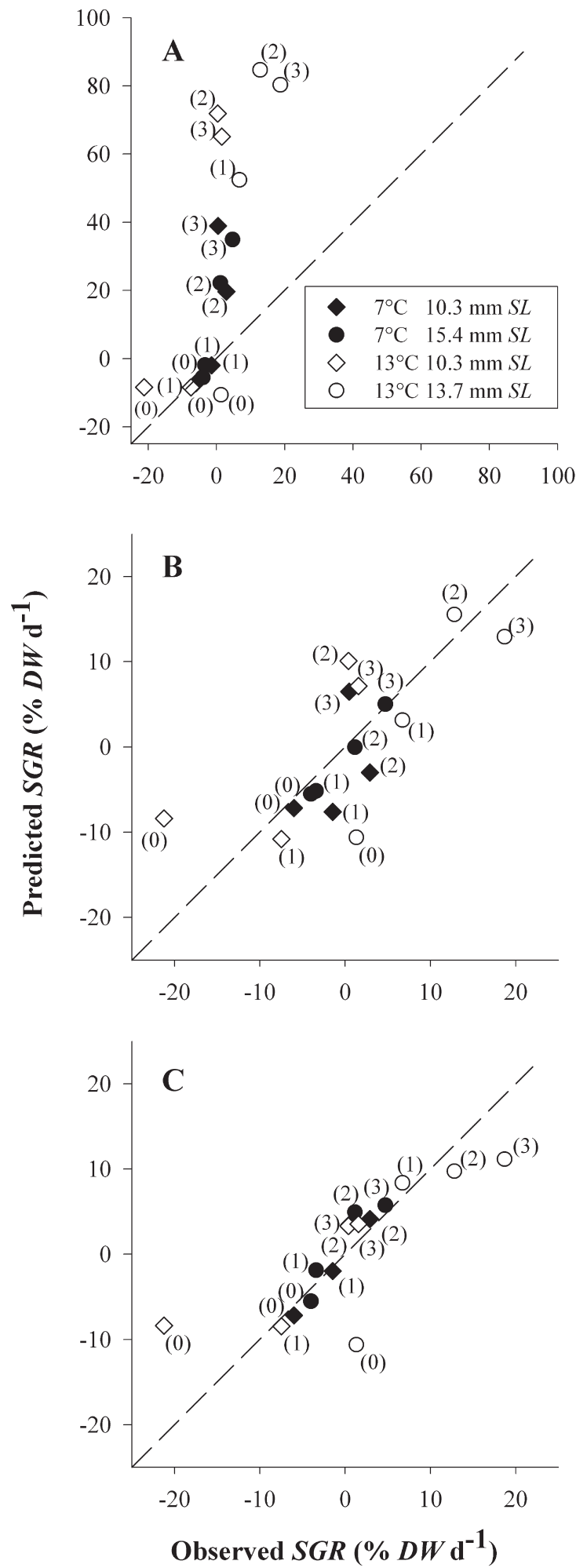

FIG. 3. - Predicted specific growth rate $\left(S G R, \% D W \mathrm{~d}^{-1}\right)$ over the experimental period for the four growth trials based on feeding strike frequency and bioenergetic budget compared to observed $S G R$. A: No adjustment of parameters (base case); B: Feeding activity in all treatments reduced to $12 \%$, note different scaling on $\mathrm{x}$ - and $\mathrm{y}$-axes; C: Assimilation efficiency reduced; Numbers denote prey environment: (0) no, (1) small, (2) medium, (3) large prey. Dashed line indicates $1: 1$ relationship. aging $\left(R_{\mathrm{A}}\right)$ (see Buckley et al., 2000). Simultaneous measurements of larvae swimming activity and respiration are scarce (Hunt von Herbing and Boutilier, 1996; Ruzicka and Gallager, 2006) and have not been made on Atlantic herring. Our modelled estimates of $R_{\mathrm{A}}$ were obtained using a $k$-ratio of 2.0 , which appears to be robust based on a) the observed rate of weight loss of starved herring and $b$ ) a similar magnitude of the difference in $R$ (2.0 to 2.5 ) measured at the same temperature for anaesthetised (Kiørboe et $a l ., 1987)$ and active herring larvae confined to small chambers (Peck unpublished data). However, as is the case in the vast majority of larval respirometry studies, the level of activity occurring during these latter measurements was unknown.

Since parameters representing metabolic losses appeared robust, model overestimates of growth in larvae feeding on more suitable prey could have stemmed from either food consumption rates or assimilation efficiencies that were too high. These two possibilities were explored in the following scenarios.

\section{Temporal variability in feeding}

Modelled estimates of $C$ based on observed feeding strike frequency $(F S F)$ were, in some cases, unrealistically high (e.g. $>4000$ nauplii $\operatorname{larva}^{-1} \mathrm{~d}^{-1}$ in the $13^{\circ} \mathrm{C}, 13.7 \mathrm{~mm} \mathrm{SL}$ trial). Direct estimates of the food consumed by larvae (based on the number of prey added to the tanks at the beginning of the trial and the number remaining at the end) were available. Unfortunately, it is not possible to estimate food consumption rates from counts of copepods since a) natural copepod mortality was not assessed (e.g. by including a tank that contained copepods but no fish larvae) and b) the feeding contribution of the small percentage of larvae that died in tanks was unknown. Interestingly, a reduction of observed $F S F$ by a single factor $(0.11)$ for all feeding treatments and all trials led to good agreement between the predicted and observed values (Fig. 3B). Predicted and observed growth agreed well with an average residual $( \pm$ SD) of $5.0( \pm 0.3)$ and had a linear relationship $\left(r^{2}=0.5 ; p<0.01\right)$ with a slope of $0.7( \pm 0.2)$. After the adjustment ( $89 \%$ reduction) in $F S F$, modelled food consumption rates were between 1 and 12 prey items larva ${ }^{-1} \mathrm{~h}^{-1}$ except in one case (34 prey larva ${ }^{-1} \mathrm{~h}^{-1}$ ). All of these estimates are well within the range of food consumption rates calculated from larval herring gut content analyses (Hauss, 2008). One explanation for this could be that FSF repre- 
TABLE 2. - Average residuals $\left(\% D W \mathrm{~d}^{-1}\right)$ for different temperatures $\left(7\right.$ and $\left.13^{\circ} \mathrm{C} ; \mathrm{n}=8\right)$, prey sizes (no, small, medium and large prey; $\mathrm{n}=4$ ), and ontogenetic stages (larval $S L \sim 10$ and 14 to $15 \mathrm{~mm}, \mathrm{n}=8$ ) in the three scenarios.

\begin{tabular}{lcccc}
\hline $\begin{array}{l}\text { Average residuals } \\
( \pm \text { standard deviation })\end{array}$ & & No adjustment & $F S F$ reduced & $\beta$ reduced \\
\hline Temperature & $7{ }^{\circ} \mathrm{C}$ & $-13.1( \pm 15.8)$ & $-1.4( \pm 3.8)$ & $-0.9( \pm 1.9)$ \\
& & $-39.9( \pm 34.2)$ & $-0.8( \pm 8.4)$ & $0.5( \pm 7.4)$ \\
Prey environment & no prey & $0.4( \pm 10.2)$ & $0.4( \pm 10.2)$ & $0.4( \pm 10.2)$ \\
& small prey & $-11.4( \pm 22.9)$ & $-1.7( \pm 1.8)$ & $-0.4( \pm 1.4)$ \\
& medium prey & $-45.3( \pm 30.5)$ & $-1.6( \pm 5.5)$ & $-1.3( \pm 3.1)$ \\
Large prey & $-48.5( \pm 16.7)$ & $-2.2( \pm 7.3)$ & $-2.4( \pm 4.8)$ \\
& $\sim 10 \mathrm{~mm}$ & $-25.1( \pm 29.4)$ & $2.8( \pm 4.5)$ & $-2.4( \pm 4.5)$ \\
& $\sim 15 \mathrm{~mm}$ & $-27.3( \pm 30.7)$ & & $-2.0( \pm 5.3)$ \\
\hline
\end{tabular}

sented foraging by all larvae at all times but capture success of prey was markedly lower than expected due to the high concentrations of prey $\left(2 \mathrm{ml}^{-1}\right)$ used in the present growth trials. Marcotte and Browman (1986) suggested that capture success is not merely a function of relative prey size, but may decline at high prey concentrations $\left(>0.4 \mathrm{ml}^{-1}, 25 \mathrm{~mm}\right.$ Salmo salar alevins) due to 'sensory overload' (i.e. perceptual confusion in extremely high prey concentrations that may hamper larvae from focusing on single prey items). In the present study, capture success was not measured, however, values of FSF were within the range of those ( 0.3 to $\left.1.0 \mathrm{~min}^{-1}\right)$ observed by other researchers for herring at 10 - to 100 -fold lower $(0.02$ to 0.2 copepods $\mathrm{ml}^{-1}$ ) prey concentrations (Munk and Kiørboe, 1985).

\section{Patch-feeding scenario}

Intensive feeding by larval fish in areas of high prey concentration may increase gut evacuation rates and decrease assimilation efficiency of ingested prey items (Werner and Blaxter, 1980; Boehlert and Yoklavich, 1984; Theilacker, 1987; Peck and Daewel, 2007). In this scenario, we decreased assimilation efficiency by the degree of potential over-filling of the available gut volume. With a gut capacity of $3.06 \%$ larval $D W$ (Pepin and Penney, 2000) and gut evacuation rate ranging between 0.37 and $0.81 \mathrm{~h}^{-1}, C_{\mathrm{MAX}}$ values were expected to range between 19 and $35 \%$ larval $D W \mathrm{~d}^{-1}$, while estimates of food consumption rate based on mean FSF were as high as 200 to $500 \%$ $D W \mathrm{~d}^{-1}$ in some cases.

Observed and modelled specific growth rates agreed more closely after this adjustment compared with the base case (see Fig. 3C) or scenario 1 (food consumption reduction). Also, modelled growth rate estimates were less variable, and no trend was ob- served in residuals with respect to the three prey sizes, two larval sizes or two water temperatures (Table 2), which indicates that the model performed well across different experimental conditions. In some cases, the adjustment led to values of assimilation efficiency that were extremely low compared to the base model (no adjustment) in which the assimilation efficiency was between 42 and 66\% (calculated using Equation [3] in Table 1). At small prey sizes, $\beta$ was not reduced except in the $13^{\circ} \mathrm{C}, 13.7 \mathrm{~mm} \mathrm{SL}$ larvae experiment. At medium prey sizes, $\beta$ values were 14 to $15 \%$ at $7^{\circ} \mathrm{C}$ and 4 to $6 \%$ at $13^{\circ} \mathrm{C}$, while at large prey sizes, $\beta$ values ranged between 4 and $8 \%$ for both temperatures. However, there is a general lack of experimental data (or agreement in the presence of data) concerning the assimilation efficiency of larval clupeids in different feeding regimes and developmental stages. For example, a nitrogen absorption coefficient of 48 to $83 \%$ was determined (Klumpp and Westernhagen 1986) and carbon assimilation rates have been reported to be $90 \%$ (Pedersen and Hjelmeland 1988) and between 38.5 and 68.2\% (Boehlert and Yoklavich 1984), these last estimates decreased as prey concentration increased.

\section{Reconciling model estimates and observed data}

What is the explanation of the discrepancy between observed foraging behaviour (feeding strike frequencies) and "biologically reasonable" rates of food consumption by larval herring? In our opinion, there are at least three possible explanations which are not mutually exclusive.

First, it is possible that there were large differences in the foraging activity among larvae in the same group, and that the observed FSF (Fig. 2) represented the behaviour of only a small percentage of the individuals in the group. This appears reasonable 
given that there were large differences in RNA-DNA ratios (and thus SGRs, Buckley et al., 2008) among larvae in the same tank in all fed treatments in each trial (Hauss, 2008). However, modelled growth rates in each treatment (base case, no adjustments) were still almost four to five times higher than the mean of the top quartile of larval $S G R$ s in each tank (individual $S G R$ s obtained from measurements of RNADNA ratios at the specific temperature). Therefore, the inter-individual variation alone does not explain the discrepancy.

A second explanation is that $F S F$ observations were relevant for only a small percentage of the time for each larva. In every trial and each prey size treatment, larvae used the entire area of the tank but the FSF could only be measured for a larva when it was not in contact with the tank wall, the tank bottom or the water surface. We did not quantify the amount of time that larvae spent at these tank "edges". Munk and Kiørboe (1985) estimated the proportion of time larval herring swam along the tank wall to be 15 to $40 \%$ in larger tanks (170 L) and corrected estimates of food consumption rates accordingly. Our tanks were smaller (16 L) and thus the correction factor required for our "tank effect" may be larger. However, even among free-swimming larvae, the variability in feeding behaviour (Fig. 2) was high, and $30 \%$ of all observed individuals $(n=313)$ did not attempt feeding strikes during the three-minute observation period. We therefore conclude that, in addition to artificial constraints on swimming behaviour, there is considerable temporal variability in foraging activity of herring larvae.

A third explanation is that, as the feeding rates were indeed extremely high for larvae in tanks, gut overfilling occurred and assimilation efficiency was markedly reduced. As previously mentioned, reduced assimilation efficiency $(\beta)$ has been reported for larvae foraging within high prey concentrations. However, to fit the model to the experimental data, it was necessary to reduce $\beta$ to extremely low values, and it is unknown whether this is realistic. It is therefore not possible to entirely disentangle the two mechanisms (temporal variability and reduced assimilation).

\section{CONCLUSION}

In the present study, we made a simple assessment of larval herring IBM physiological parameterisations by comparing observed and modelled growth rates of different sizes of larvae at different water temperatures that were provided different prey sizes. Model parameters representing metabolic energy losses in unfed larvae appeared to be robust, including $k$-ratios employed to convert between $R_{\mathrm{S}}$ (inactive, night) and $R_{\mathrm{A}}$ (active, daytime) rates of energy loss. In fed larvae, the model greatly overestimated SGR except for larvae feeding on suboptimal (small) prey. The introduction of correction factors to account for either temporal variability in foraging behaviour (scenario 1) or reduced assimilation efficiency at high feeding rates (scenario 2) resulted in good agreement between modelled and observed growth across larval ages, prey environments, and temperatures.

Future laboratory trials are needed to test larval fish IBM estimates of foraging and growth, and several recommendations can be made based on our results. First, growth trials that utilise groups of larvae are useful since they capture general (average) impacts of environmental factors (e.g., growth versus temperature and prey size). Second, the parameter rates of Equation 1 (e.g., $C, G, R, \beta$ ) should also be measured on individual larvae, as our results demonstrated that large variability can exist in food consumption and growth rates among larvae in the same environment. This challenges experimentalists by highlighting the importance of making physiological and behavioural measurements of the same individual. Moreover, it shows modellers that including individual variability in physiological and behavioural attributes may be necessary to adequately model the survival and growth of individuals within variable environments.

\section{REFERENCES}

Batty, R.S. - 1987. Effect of light intensity on activity and foodsearching of larval herring, Clupea harengus: a laboratory study. Mar. Biol., 94: 323-327.

Berggreen, U., B. Hansen and T. Kiørboe. - 1988. Food size spectra, ingestion and growth of the copepod Acartia tonsa during development: implications for determination of copepod production. Mar. Biol., 99: 341-352.

Blaxter, J.H.S. - 1968. Visual Thresholds and Spectral Sensitivity of Herring Larvae. J. Exp. Biol., 48: 39-53.

Boehlert, G.W. and M.M. Yoklavich. - 1984. Carbon assimilation as function of ingestion rate in larval Pacific herring, Clupea harengus pallasi Valenciennes. J. Exp. Mar. Biol. Ecol., 79: 251-262.

Brett, J.R. and T.D.D. Groves. - 1979. Physiological energetics. In: W.S. Hoar, D.J. Randall and J.R. Brett (eds.), Fish Physiology, pp. 279-352. Academic Press, New York.

Buckley, L.J., E.M. Caldarone and C. Clemmesen. - 2008. Multispecies larval fish growth model based on temperature and fluorometrically derived RNA/DNA ratios: results from a metaanalysis. Mar. Ecol. Prog. Ser., 371: 221-232. 
Buckley, L.J. and D.W. Dillman. - 1982. Nitrogen utilization by larval summer flounder, Paralichthys dentatus (Linneaus). J. Exp. Mar. Biol. Ecol., 59: 243-256.

Buckley, L.J., R.G. Lough, M.A. Peck and F.E. Werner. - 2000. Comment: Larval Atlantic cod and haddock growth models, metabolism, ingestion, and temperature effects. Can. J. Fish. Aquat. Sci., 57: 1957-1960.

Daewel, U., M.A. Peck, W. Kühn, M.A. St. John, I. Alekseeva and C. Schrum. - 2008. Coupling ecosystem and individual-based models to simulate the influence of climate variability on potential growth and survival of larval sprat in the North Sea. Fish Oceanogr., 17: 333-351.

Fiksen, Ø. and A. Folkvord. - 1999. Modelling growth and ingestion processes in herring Clupea harengus larvae. Mar. Ecol. Prog. Ser., 184: 273-289.

Fiksen, Ø. and B.R. MacKenzie. - 2002. Process-based models of feeding and prey selection in larval fish. Mar. Ecol. Prog. Ser., 243: 151-164.

Folkvord, A., G. Blom, A. Johannessen and E. Moksness. - 2000 Growth-dependent age estimation in herring (Clupea harengus L.) larvae. Fish. Res., 46: 91-103.

Folkvord, A., H. Hoie, A. Johannessen and T. Solbakken. - 2009. Effects of prey concentration, light regime, and parental origin on growth and survival of herring larvae under controlled experimental conditions. ICES J. Mar. Sci.

Geffen, A.J. - 2009. Advances in herring biology: from simple to complex, coping with plasticity and adaptability. ICES J. Mar. Sci.

Hauss, H.M. - 2008. Impacts of prey field characteristics on foraging and condition of larval herring (Clupea harengus). Diploma thesis, Christian-Albrechts-Universität, Kiel.

Heath, M., B. Scott and A.D. Bryant. - 1997. Modelling the growth of herring from four different stocks in the North Sea. J. Sea Res., 38: 413-436.

Hinrichsen, H.-H., A. Lehmann, C. Möllmann and J.O. Schmidt. - 2003. Dependency of larval fish survival on retention/dispersion in food limited environments: the Baltic Sea as a case study. Fish. Oceanogr., 12: 425-433.

Hunt von Herbing, I. and R.G. Boutilier. - 1996. Activity and metabolism of larval Atlantic cod (Gadus morhua) from Scotian Shelf and Newfoundland source populations. Mar. Biol., 124: 607-617.

Kiørboe, T., P. Munk and K. Richardson. - 1987. Respiration and growth of larval herring Clupea harengus: Relation between specific dynamic action and growth efficiency. Mar. Ecol. Prog. Ser., 40: 1-10.

Klumpp, D.W. and H. Westernhagen. - 1986. Nitrogen balance in marine fish larvae: influence of developmental stage and prey density. Mar. Biol. 93: 189-199.

Lough, R.G., L.J. Buckley, F.E. Werner, J.A. Quinlan and K.P. Edwards. - 2005. A general biophysical model of larval cod (Gadus morhua) growth applied to populations on Georges Bank. Fish. Oceanogr., 14: 241-262.
Marcotte, B.M. and H.I. Browman. - 1986. Foraging behaviour in fishes: perspectives on variance. Environ. Biol. Fish., 16: 25-33.

McGurk, M.D. - 1984. Effects of delayed feeding and temperature on the age of irreversible starvation and on the rates of growth and mortality of Pacific herring larvae. Mar. Biol., 84: 13-26.

Miller, T.J. - 2007. Contribution of individual-based coupled physical-biological models to understanding recruitment in marine fish populations. Mar. Ecol. Prog. Ser., 347: 127-138.

Munk, P. - 1992. Foraging behaviour and prey size spectra of larval herring Clupea harengus. Mar. Ecol. Prog. Ser., 80: 149-158.

Munk, P. and T. Kiørboe. - 1985. Feeding behaviour and swimming activity of larval herring (Clupea harengus) in relation to density of copepod nauplii. Mar. Ecol. Prog. Ser., 24: 15-21.

Peck, M.A. and U. Daewel. - 2007. Physiologically based limits to food consumption, and individual-based modeling of foraging and growth of larval fishes. Mar. Ecol. Prog. Ser., 347: 171-183.

Pedersen, B.H. and K. Hjelmeland. - 1988. Fate of trypsin and assimilation efficiency in larval herring (Clupea harengus) following digestion of copepods. Mar. Biol. 97: 467-476.

Pepin, P. and R. Penney. - 2000. Feeding by a larval fish community: impact on zooplankton. Mar. Ecol. Prog. Ser., 204: 199-212.

Rosenthal, H. - 1969. Untersuchungen über das Beutefangverhalten bei Larven des Herings Clupea harengus. Mar. Biol., 3: 208-221.

Ruzicka, J.J. and S.M. Gallager. - 2006. The importance of the cost of swimming to the foraging behavior and ecology of larval cod (Gadus morhua) on Georges Bank. Deep-Sea Res. II, 53: 2708-2734.

Skajaa, K., A. Fernö and A. Folkvord. - 2003. Swimming, feeding and predator avoidance in cod larvae (Gadus morhua L.): tradeoffs between hunger and predation risk. In: H.I. Browman and A.B. Skiftesvik (eds.), The Big Fish Bang. Proceedings of the 26th Annual Larval Fish Conference, pp. 105-121. Bergen.

Theilacker, G.H. - 1987. Feeding ecology and growth energetics of larval northern anchovy, Engraulis mordax. Fish. Bull., 85: 213-228.

Theilacker, G.H. and A.S. Kimball. - 1984. Comparative quality of rotifers and copepods as foods for larval fishes. Calif. Coop. Oceanic Fish. Invest. Rep. 25: 80-85.

Walton, W.E., N.G. Hairston and J.K. Wetterer. - 1992. Growthrelated constraints on diet selection by sunfish. Ecology. 73: 429-437.

Werner, F.E., J.A. Quinlan, R.G. Lough and D.R. Lynch. - 2001. Spatially-explicit individual based modeling of marine populations: a review of the advances in the 1990s. Sarsia. 86: 411-422.

Werner, R.G. and J.H.S. Blaxter. - 1980. Growth and survival of larval herring (Clupea harengus) in relation to prey density. Can. J. Fish. Aquat. Sci., 37: 1063-1069.

Received November 15, 2008. Accepted June 25, 2009.

Published online October 5, 2009. 